\title{
VIZUALINĖS IRONIJOS ŽANRAI MEMUOSE: DEKONSTRUOJANT ROŽINIO PUDELIO MADOS MEMUS
}

\author{
Memetic Genres of Visual Irony: \\ Deconstructing the Pink Poodle Fashion Memes
}

\section{SUMMARY}

The aim of the article is to disentangle the mix of humour genres in the visual domain by following the scheme of Kreuz and Roberts which was produced for literary genres of irony such as satire, sarcasm, and parody (1993). The analysis is based on fashion memes created by the Pink Poodle, an imaginary persona operating in Lithuanian social networks and a prolific producer of original fashion memes. The article reviews Pink Poodle memes, deconstructing the scheme of 'joke' production. Analysing visual and verbal elements of Poodle's memes, the author is looking into the mechanics of humour as it occurs in a fashion meme and examining the differences among irony, parody, sarcasm and satire in the visual domain of memes.

\section{SANTRAUKA}

Straipsnyje siekiama išskirti vizualaus humoro žanrų ribas, naudojantis schema, sukurta Kreuzo ir Roberts ironijos skirtumams literatūriniuose žanruose apibrèžti (1993). Analizė grindžiama mados memais, sukurtais lietuviškų socialinių tinklų personažo, produktyvaus mados memų kūrejo Rožinio pudelio. Analizuojant Rožinio pudelio memų vizualiuosius ir verbalinius elementus tekste dekonstruojamas mados memo kuriamas pokšto mechanizmas. Tokiu būdu siekiama suprasti mados memo humoro atsiradimo procesą bei vizualiuoju aspektu apibrěžti skirtumus tarp ironijos, parodijos, satyros bei sarkazmo mados memuose.

$\mathrm{T}$ he most widespread concept of irony is based on the definition plains it as 'A mode of speech in which provided by Samuel Johnson, who exthe meaning is contrary to the words' (in Colebrook 2004: 17). In other words, 
irony occurs when a saying expresses something that it is not or says the opposite of what is meant, like a pretendedly enthusiastic remark 'What a wonderful weather!' on a stormy day. Kreuz and Roberts argue that irony is not a [literary] genre, but a "complex rhetorical device sometimes used by [...] genres" (Kreuz \& Roberts, 1993: 98). According to Magill, irony is "an entire worldview" (Magill 2007: 74), an attitude that characterizes the thinker rather than the attitude itself. The power of irony, beyond its entertainment value, rests in its ability to convey "a broader comprehension of social reality, political preferences, and power, all by manipulating the rules of language itself" (Magill 2007: 4). Claiming the opposite of the obvious, the ironic speaker is twisting the regular communication process, presuming that their audience is as intelligent as themselves and can decipher the contradictory message adequately (see Colebrook 2004).

Internet memes are a perfect representation of the ironic mode of thinking as defined by Magill, because their life depends on the audience who is witnessing them and spreading them further. Unlike their ancestors, hand-drawn car- toons and caricatures, internet memes are composed from ready-made bits and pieces of previous cultural narratives (film stills, photographs, cartoons, verbal phrases, etc.), thus 'reading' the irony of a meme message demands quite detailed knowledge of the field on the part of the audience. Memetic irony has been noted by a number of scholars (Denisova 2020, Skjulstad 2018, Kim 2019), but the mechanics of humour applied by memes has been little analyzed. A very relevant analysis has been performed by Marta Dynel (2016), who has researched the mechanics of visual humour of Advice Animals/ Animal meme templates. The latter are analyzed as visual-verbal jokes in the framework of the incongruity-resolution model, yet with emphasis on their humorous rather than ironic aspect. Fashion meme research, in its turn, is yet in its infancy, limited to two published articles (by the time of writing in July 2021; see Skjulstad 2018, Kim 2019). The following text contributes to the fashion meme study by looking at a particular producer of fashion memes, a Lithuaniabased social media account operated by the Pink Poodle - an imaginary personality that serves as a pseudonym for a group of fashion criticism enthusiasts.

\section{VISUAL IRONY AND INTERNET MEMES}

The term of irony has been known since Greek comedy, where it represented a character type who got the best of opponents through wit and resourcefulness (Beckson \& Ganz in Kreuz \& Roberts 1993: 98). Kreuz and Roberts point out four basic types of irony: Socratic irony, irony of fate, dramatic irony, and verbal irony. They share only one feature: a discrepancy between mental representations and states of affairs. The manifestations of the discrepancies are what distinguishes them one from another (Kreuz \& Roberts 1993: 98). In their 
article Kreuz and Roberts discriminate among irony, satire and parody in literary texts, showing how the employment of these different literary devices influence the impact of comedic texts on the audience, and what tools are used to achieve that.

A similar procedure in relation to the visual domain would help to develop the audience's perception as well as serve as a useful functional tool for humorists. It is what the present article aims at, namely, to understand the origin of visual 'jokes' by deconstructing them and following the mechanics of visual humour. The selected field of investigation - internet memes in general, and fashion memes in particular - is highly relevant to the issue of the audience that is at the core of any discussion on irony. Because, as many authors have pointed out (Behler 1993; Hutcheon 1995), one of the fundamental aspects of the ironic mode is the context. According to Colebrook, irony requires a specific context in order to be (fully) appreciated: "At the very least, irony is elitist: to say one thing and mean another, or to say something contrary to what is understood, relies on the possibility that those who are not enlightened or privy to the context will be excluded" (Colebrook 2004: 18). As Magill puts it, the use of irony "adds a certain spice of insiderness to all conversations" (Magill 2007: 3). Only the insiders will be able to understand the joke and perceive the intention of irony.

Accepting the claim of Magill that irony is a mode of thinking, we are then obliged to perceive and analyze its various forms as means of expression, visual irony being one of them. Visual ironic, then, should be perceived as an expression of the ironic attitude through visual means, i.e., instead of a mode of speech in which the meaning is contrary to words, we have a mode of visual representation that creates meaning contrary to what it seems to be claiming through its image.

Biljana Scott in her analysis of the visual ironic in photography defines an ironic image as one that would establish a 'usual scheme of things' or a system of belief, and question it at the same time, presenting an element of incongruity. She provides the example of Jones Griffith's photograph Human remains, Cambodia, 1980 (Scott 2004: 43). The image shows a smile of reclining Buddha over a mass of human bones and skulls in the foreground. The irony of this photograph resides in the incongruity of two incompatible orders of experience inhabiting the same frame: a statue of a smiling deity who is associated with calm, religious concentration and blessing as well as protection, and human skulls and bones around it witnessing the presence of horror, violence and death. There is no text to help the viewer to distinguish between what is said and what is meant, or what is being cited ironically as opposed to what is being said seriously. Instead, "in order to appreciate the irony involved, we appeal to our knowledge of the world, to the symbolic value of the two components in the picture, and to their incompatibility in the usual scheme of things" (ibid). In other words, the reading of the ironic in a visual text depends on the reader's experience as well as their knowledge of the matters of the world and the very perception of it. 
Visual irony in memes has been discussed by a number of researchers, yet the definition of the term that could be relied on is difficult to locate. It seems that authors use the term "irony" quite generally, without additional explanation about the embedded contents of the concept they employ. The text below will try to disentangle, where possible, the intertwined notions of satire, irony and parody in fashion memes, following the scheme built around verbal irony by Kreuz and Roberts (1993). Understanding the differences may help to develop a scheme of generic distinctions that could be useful in further investigation of the bottomless realms of memetic universe.

\section{PINK POODLE FASHION MEMES}

Pink Poodle is one of the most famous personalities in Lithuanian fashion and definitely the most famous fashion critic of the country. It is a fictional character of social media, a pseudonym for a collective of four fashion fans. The Pink Poodle Facebook account under the title 'Look, Mamma, I'm a Celebrity' (Mama, žiūrèk, aš - Selebriti) was launched 28 of April 2016 as a joke, with the aim to practice publicly the most favourite occupation of a group of friends - to gossip about the public looks of local as well as global celebrities.

Currently the 'Look, Mamma, I'm a Celebrity' Facebook account has 42,013 followers, and the Instagram account @ pinkpoodlecelebrity enjoys $15.1 \mathrm{~K}$ followers' audience (as of 17 July 2021). Both channels are used as parallel to one another - the same post would be put on Facebook and Instagram simultaneously, with (almost) identical content.

As mentioned above, the Pink Poodle account was created for making fun of people's clothes that they wear in public events, when the dress is considered inappropriate, not stylish or fashionable enough. The usual method of meme creation is the one of association - the image of an outfit taken from some publicly available source (e.g. a magazine photoarchive) is posted together with another image (or several images), the one(s) that embodies the association. The juxtaposition creates the effect of incongruity between the original intention of the person who chose to wear the outfit in question, and the way that Poodle sees the final result of it. The image is accompanied by a verbal text with commentary which accomplishes the meme. For example, Fig. 1 demonstrates an outfit of a gentleman who was wearing a light blue suit with white shoes for a public event. It was the model of the trousers and the particular form of the shoes that, presumably, inspired the association with (male) ice dancing costume. The figure of the original outfit wearer has been photoshopped into an ice-arena background, and the skates have been added instead of the shoes. The resulting image is placed next to the original, in the central part of the composition. The accompanying verbal commentary expands on the implied hint: "Sometimes the themes for parties are "Tropics", "Blue blood", "Disco", "Nuns and devils", and here, perhaps, it was "Skate with a star"?" 

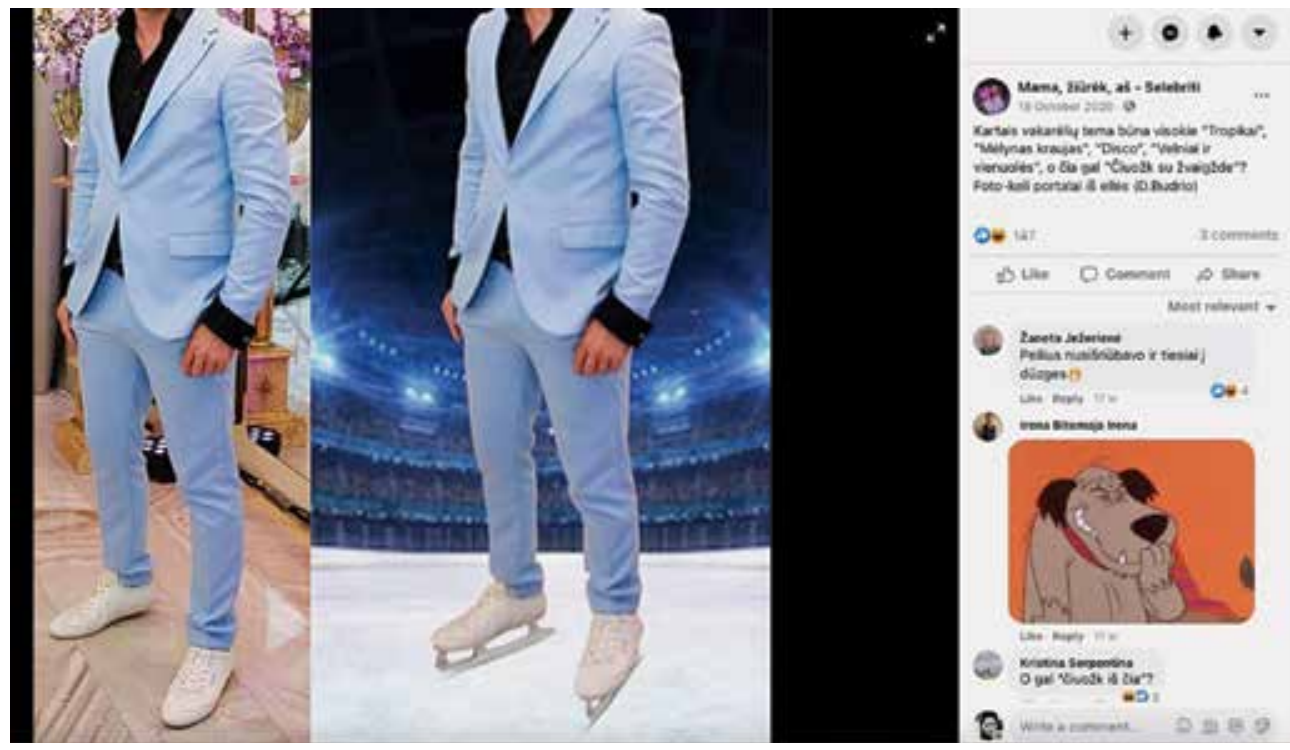

Fig. 1

Like many other fashion memes of the type, Poodle's posts seem to register the actual process of joke creation: the original image is the intention of its author (i.e. the creator of the outfit that is being parodied by Poodle), while the final image produced by Poodle - the collage - is the visual joke we get of the dress.

The interesting point here is the difference between the processes of the visual and the verbal humour that we as the audience experience. As noted by Hempleman and Samson (2008: 626), it is a spatial versus linear perception. With verbal jokes, there must be a sequential narrative that culminates in a punch line; with visual jokes, the image is perceived all at once, so the culmination comes without prior notice or preparation, and is a matter of spatial composition.

For example, the collage in Fig. 2 has been compiled without any photoshop- ping, but the effect is obvious: a model from Gucci runway reminded to Poodle characters of animated films, sheep in this case. The two animated sheep characters have the same function here - to encourage the association between the furry hat that the model is wearing and the form of a sheep 's head, emphatically the animated sheep, not an actual sheep's head. The viewer perceives the resemblance between the images instantaneously, especially because both human and animated sheep heads that are closest in their looks - i.e. of black colour - are put next to each other. The white animated sheep head has been added for enhancing the idea of sheep, as the black one is not so obviously 'sheepish'. The verbal comment announces "For me, Gucci is like zucchinis delicious and lovable, when there's not too much. But when there is a lot of zucchinis, there is no life". 

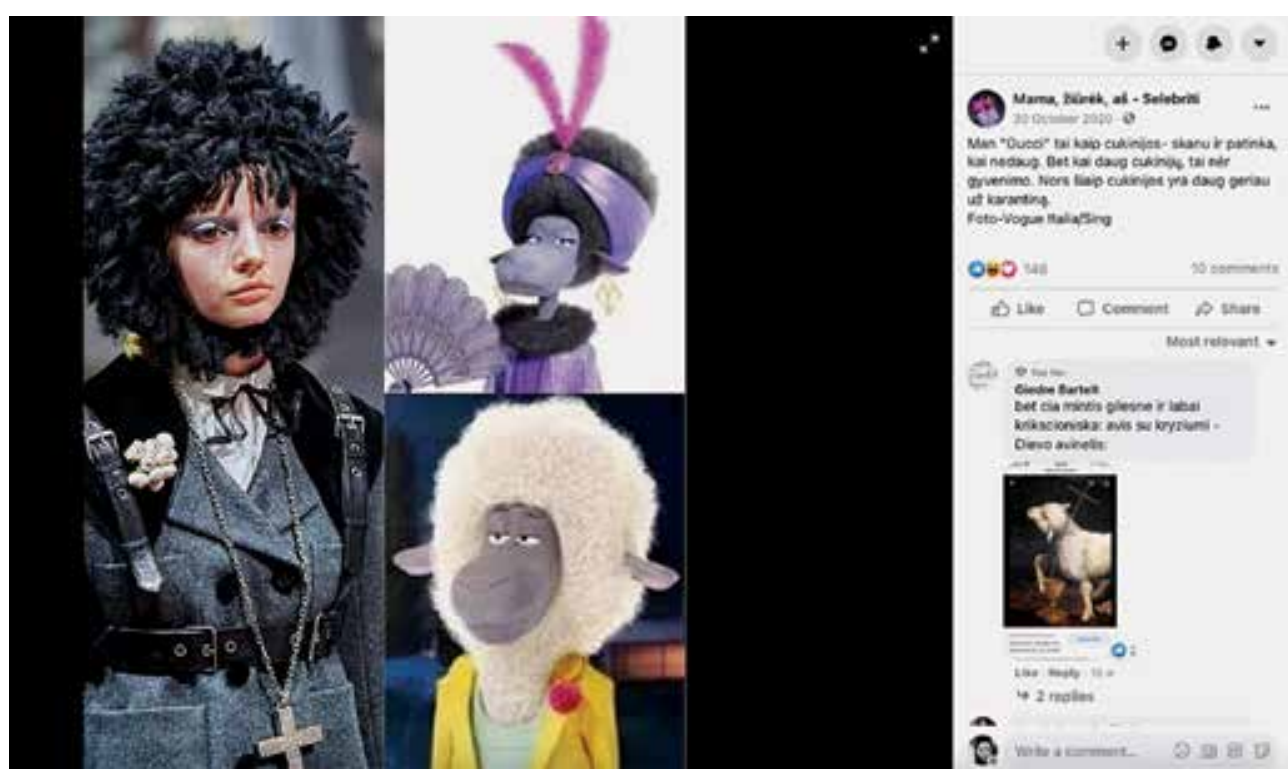

Fig. 2

Being first and foremost a visual product, (fashion) memes display principles of visual composition that are quite universal. In the case of Pink Poodle, the memes fall into several compositional types.

The first principle that is often applied is the one that corresponds the expectations of a reader of a computer screen: the primary piece of information must come at the top of the left-hand side, as it is how we read the information on the screen: from left to right, from top to bottom. Other information units follow the same direction, from left to right, as can be seen in Fig. 1, 2. The visual joke itself, however, can only be perceived by regarding the two images together at once, as noted above.

Another composition principle is making the "association" image the largest in the collage, like in Fig. 3. The original images of the celebrity figure Kim
Kardashian wearing red string underwear have been photoshopped to include the Mercedes Benz logo. Though the final image is placed on the right, but it is twice as large as the original photos, so the emphasis cannot be missed. In addition, the compositional principle here seems to suggest a linear climax of the eye-movement: the reader can follow the track of the association: first the initial photo when one catches the sight of the red line of at the bottom of the dress opening, then the second photo provides a close-up of what it is, and then - voilà the impression that Poodle had about the outfit which creates the joke.

In Fig. 4 photoshopping has not been used either. Along both sides of an image featuring Kim Kardashian wearing a lace dress photos of old wooden window frames have been added, with the one on the left exhibiting old shabby lace curtains. All the three images are of the 

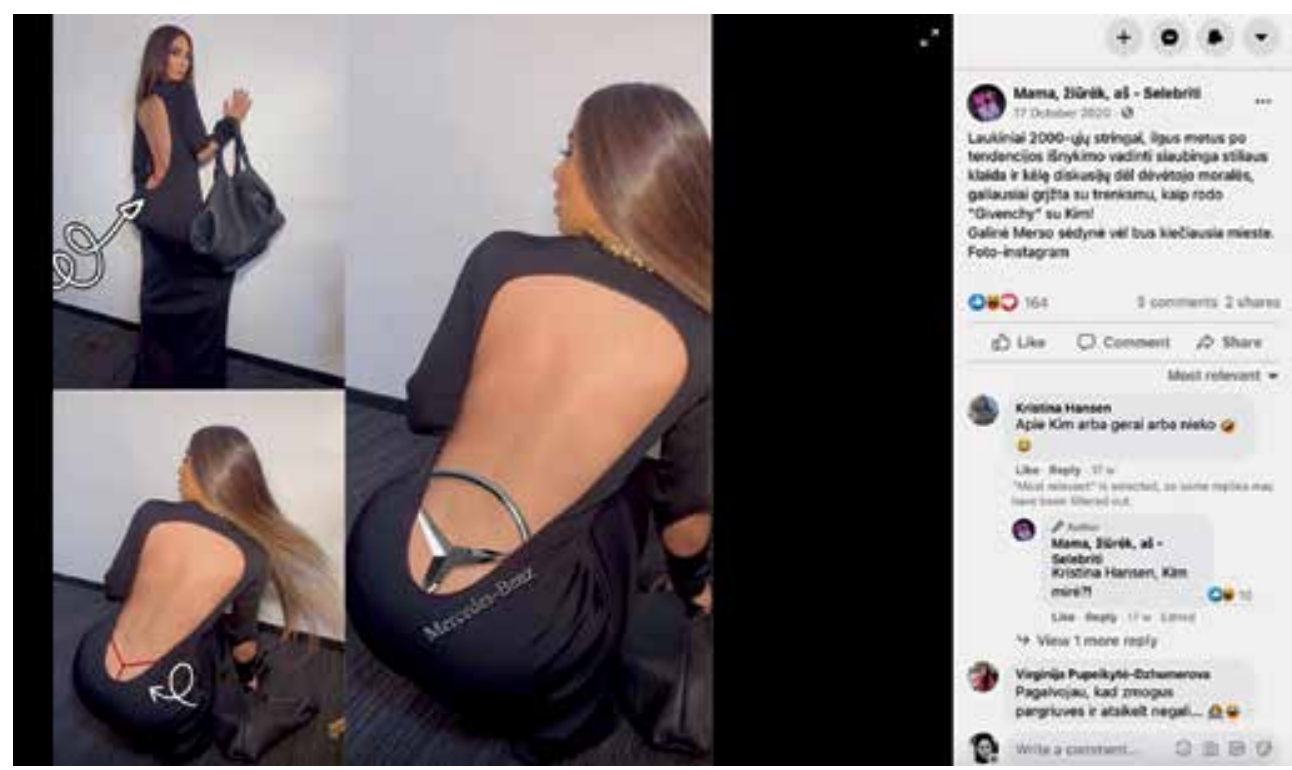

Fig. 3

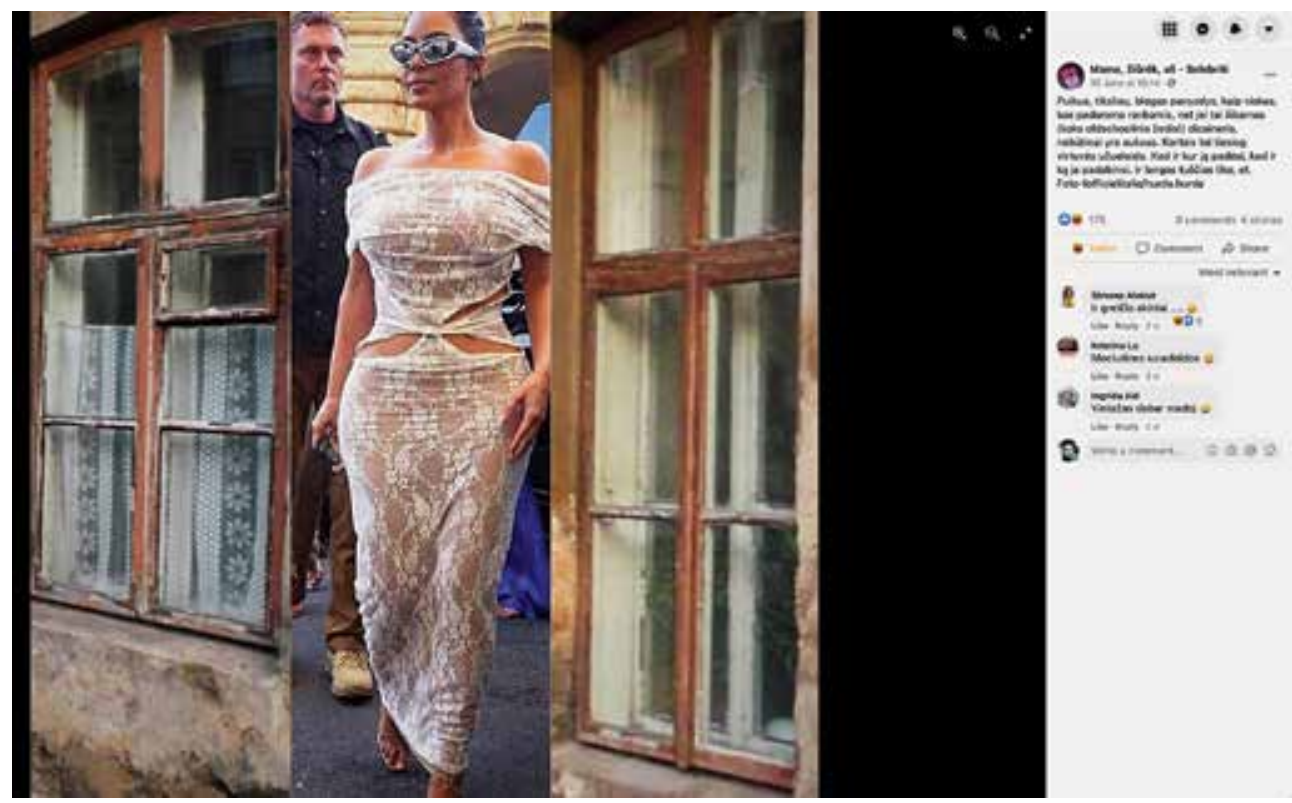

Fig. 4

same size and format, yet it is a central composition, because the human figure that is at the focus of the post occupies the central position. The similarity between shabby curtains and Kardashian's dress is not instantly obvious, because the curtain is barely visible behind the window frame. The absence of a curtain in the other window and the association itself is explained in the verbal text of 
the post: "A perfect, meaning, terrible example that everything that is hand-made, even if it is a chic (what an oldschoolish word!) designer is not necessarily gold. Sometimes it is just a kitchen curtain. Wherever you put it, whomever you adorn with it. And the window was left empty, alas".

So the meaning of the third image in the composition - the curtainless window - is made clear, as the text is implying that the shabby curtain from the other window has been used for the celebrity's dress. Despite the seemingly central composition principle, the narrative, however, maintains the left-to-right direction, as the eye of the viewer has to travel from the first image on the left the window with the curtain, then to the central image with the Kardashian's dress, and then to the right to the curtainless window. Yet the meme acquires its full meaning only when the text has been read. Like most memes produced by the Pink Poodle, visual elements serve only as background for conveying an ironic view on fashion. Their structural relations between the visual and the textual is what makes them peculiar and distinguishes them from other fashion memes.

\section{THE PECULIARITIES OF IRONY IN PINK POODLE FASHION MEMES}

Pink Poodle memes are not typical internet memes because, even though they correspond the definition of memes as "digital units of expression, intended for sharing and conveying certain meanings or emotions" (Denisova 2020: 13), they are not incomplete or half-baked jokes which is, according to Denisova, one of the remarkable distinguishing features of internet memes. A typical internet meme is a ready-made template that "demands user participation to 'finish the sentence'" (ibid), to contribute to its meaning by adding something of one's own. Pink Poodle memes are not ready-made templates, but unique products that form a complete structure. They are composed of three elements invariably: the original image, the (photoshopped) image that represents or hints the association, and the verbal element in the form of a text that is most often not a direct explanation, but a further development of the idea, or an illustra- tion of it. It is never an open structure, but always a complete three-element scheme that readers will share as a full post. Thus it is memetic only because of its visual form, not its structure. Its openness to the audience involvement lies in its invitation to a dialogue that the verbal text enhances.

The invitation, however, is never direct, and rarely a straightforward address to the reader. Most often it is a very personal opinion of Poodle on the outfit that is being ridiculed, and its intimacy of expression provokes a similarly personal response. For example, the iceskaters costume comment in Fig 1. is formulated as a 'rhetorical' question that does not require an answer, but encourages further musing on the subject: "and here, perhaps, it was "Skate with a star"?"

The readers offer their own comments: "Down with the blades and right into the afterparty"; "Or maybe "get lost"? (a play on the word 'skate' which 
means skating on ice but is also used in colloquial speech to say "get out of here/ get lost").

In Fig. 2, the likeness of Gucci runway hat to a sheep's head is accompanied by Poodle's comment that has little to do with the images themselves: Gucci style is compared to zucchini vegetable. The conceptual gaps between Gucci runway, sheep's head and zucchinis encourages an equally personal evaluation that the readers are eager to share. One of the reactions is equally remote from the runway but offers a 'deeper' insight: the user has posted an image of a little lamb with a cross - a detail of the famous artwork, the Isenheim Altarpiece painted by Mattias Grünewald, suggesting that the idea is "deeper and very Christian: a sheep with a cross - God's Lamb". To which Poodle replies: "The little Gucci of God". Another reader shares a personal childhood memory about having a similar hat, saying that " 30 years ago my ears did not get cold, for sure". Yet another reader contributes to the association game with an image from an old film with human actors playing sheep that exhibits very similar hats to that of Gucci.

In Fig. 3, Poodle's criticism of Kim Kardashian's visible red strings is quite indirect: "The wild strings of 2000s, long years after the extinction of the trend being addressed as a terrible mistake of style and provoking discussions on the morale of the wearer are coming back with a big bang, as demonstrated by "Givenchy" with Kim!

The back seat of Mercedes will again be the coolest in town."

The public reacts with precaution, as if giving a warning - the first comment says: "Of Kim, nothing but good". It hints of an ancient proverb that one should not talk ill of dead people, though the writer obviously did not have that intention. The comment most probably implies the 'untouchable' status of Kim Kardashian that some media channels promote, avoiding to criticize any single thing that she does. Yet Poodle here responds directly to the original meaning of the sentence, asking the commentator: "Has Kim died?" To which the reader must reply with an explanation that confirms the idea of Kardashian being above criticism: "As an exception, this rule is also valid for the living".

In addition, Pink Poodle memes demonstrate a peculiar version of memetic 'punctum', what Gabriele Marino calls a 'mistake' (Marino 2015: 60) that, according to Shifman, is what conveys the idea of 'incongruity', a classic mechanism of comedy (Shifman in Marino 2015: 60). Marino claims that a proper meme, that is a derived text, is about the 'mistake' which has been noticed in the pre-existing, or original text. It is selected, put under the spotlight, and spread. The 'mistake' is the 'semantic hook' that, according to Marino, catches the user's attention and provides the idea for a meme, like peculiar physical features of a public figure make them subject to parody or imitation. The bigger the 'mistake', the more whimsical the text and the more incongruity is evident (Marino 2015: 60). Shifman notes that many - if not most - of the internet memes display a situation that was not originally intended as funny (Shifman in Marino 2015: 60). Referring to Maddy Marino 
writes that such irony is a 'found irony', discovered by the 'creator-user' in the original (source) text and "perpetrated autonomously as the prominent element in the target text" (Marino 2015: 60). In the case of Pink Poodle, however, the visual part of the meme, the 'punctum', or the 'mistake', is only part of the joke and is most often merely parodic. The fashion mistake is selected, pointed out and exaggerated so that it acquires a different shape or proportion (like the iceskater's shoes in Fig. 1 or Mercedes-Benz logo in Fig. 3) and becomes funny. Yet it is the verbal commentary that makes it an ironic fashion message and completes the structure of the meme, placing the visuals in a context intended for a fashion-savvy audience. Finally, the verbal commentary almost never comes inside the image (as is typical of memes) but accompanies the image collage that is the visual 'bone' of Pink Poodle meme.

Poodle's posts, like many other fashion memes of the type, register the incongruity which produces the visual irony: the original image is the intention of the author, while the image produced by Poodle is the actual view we get of the sight. As Samson and Huber (2007) have shown, there are several locations for incongruity: text, picture, or between text and picture (in Hempleman \& Samson 2008: 624). In the case of Poodle memes, the incongruity is between text and picture, therefore the ironic effect is not produced by the image alone, but by the combination of the two. On their own, the images of Poodle's post are not ironic, just funny or parodic, in the majority of cases. They become ironic only when the text completes the communicative message. Therefore we should not speak of visual irony in the case of Pink Poodle, but the ironic worldview that is expressed through visual means.

Finally, Pink Poodle's memes exhibit no 'punch line' in the visual part of their structure. As they are not a textual narrative, instead of the punch line that creates the culminating final effect memes must develop a different concept of the joke. The punch line either does not exist or comes about in the verbal commentary that accomplishes the post. For example, in Fig. 1 and 2, laughter is provoked by the very juxtaposition of associative images - it is the association that is funny, not the original image. The 'punch line' is provided by the text of the post. The text for Fig.1 hints of a popular TV show "Dance with a star", which may imply that the ridiculed gentleman wearing blue suit with white shoes is somebody famous. The last line of the text for Fig. 2 echoes the social trends of the year 2000, when Mercedes Benz was the 'coolest' automobile brand.

\section{DISENTANGLING THE GENRES: PARODY, IRONY, SARCASM OR SATIRE?}

In the case of Pink Poodle fashion memes the ironic message is not a result of mere juxtaposition of images but occurs from a more complex scheme. The memes themselves demonstrate a variety of compositional as well as generic differences, therefore it seems worthwhile to discriminate among the domi- 
nant genres, which may lead to a better understanding of the mechanics of visual humour in general and internet fashion memes in particular.

Out of the four dominating types of irony noted by Kreuz and Roberts, verbal irony is the most readily applicable for the domain of memes because of its verbality. For the purposes of this article, the concept of verbal irony as explained by Kreuz and Roberts will be used. They define it as an intentionally made statement that is opposite to the speaker's beliefs (Haverkate in Kreuz \& Roberts 1993: 99). Translated into visual format, it will correspond the definition of visual irony provided by Scott, i.e. a visual incongruity in an image between a seeming intention of an image and the actual effect that it is producing. As noted above, Pink Poodle memes do not produce visual irony, they create a complex form of irony that is born from combining a juxtaposition of several images linked by association with a verbal text that puts the association in a particular context. The most frequently achieved effect is that of sarcasm, which Kreuz \& Roberts explain as a subtype of verbal irony in which "the attitude expressed is typically negative and directed toward an individual or a group (Kreuz \& Glucksberg in Kreuz \& Roberts 1993: 99). Following this definition of sarcasm, it is possible to claim that most of Pink Poodle's posts that focus on celebrities are sarcastic, for the very reason of their existence is negative criticism directed towards the individual whose photograph is being discussed. Important note: not individuals themselves, but the outfit that they are wearing at that moment. In Fig. 1, a person's party outfit is compared to an ice-skater's costume; in Fig. 2. Kim Kardashian's dress detail is twisted to remind of a Mercedes Benz logo; in Fig. 6 the haute couture fabric of Gucci suit worn by a world-famous singer for a world-famous occasion is likened to that of Russian villagers' festive garment, in Fig. 4 Kim Kardashian's dress is likened to an old shabby kitchen curtain. Both visual and verbal elements express the negatively critical attitude in the form of a joke or representation of an incongruity, that is why they may be termed sarcastic. Sarcasm as a genre of irony is the dominating mode of expression in Pink Poodle's memes.

Parody can be thought of as imitation, intended to ridicule or to criticize (Holman \& Harmon in Kreuz \& Roberts 1993: 102). The theory of echoic mention, essential in understanding the mechanism of parody, requires that the features of the parodied subject would be replicated in its humorous imitation - exaggerating physical, psychological or other features of the subject is what provokes laughter and creates the ridicule. With verbal elements, echoic mention defines the method of repeating the words and thoughts of another person (Kreuz \& Roberts 1993: 100). With visual elements, it is the exaggerated emphasis of the ridiculed features - too large a nose or too short legs, etc. In the case of Poodle memes, parody is rather easily decipherable, as the meme would demonstrate an echoed version of the outfit that is under focus, but in an exaggerated manner - i.e., something would be photoshopped to emphasize the 


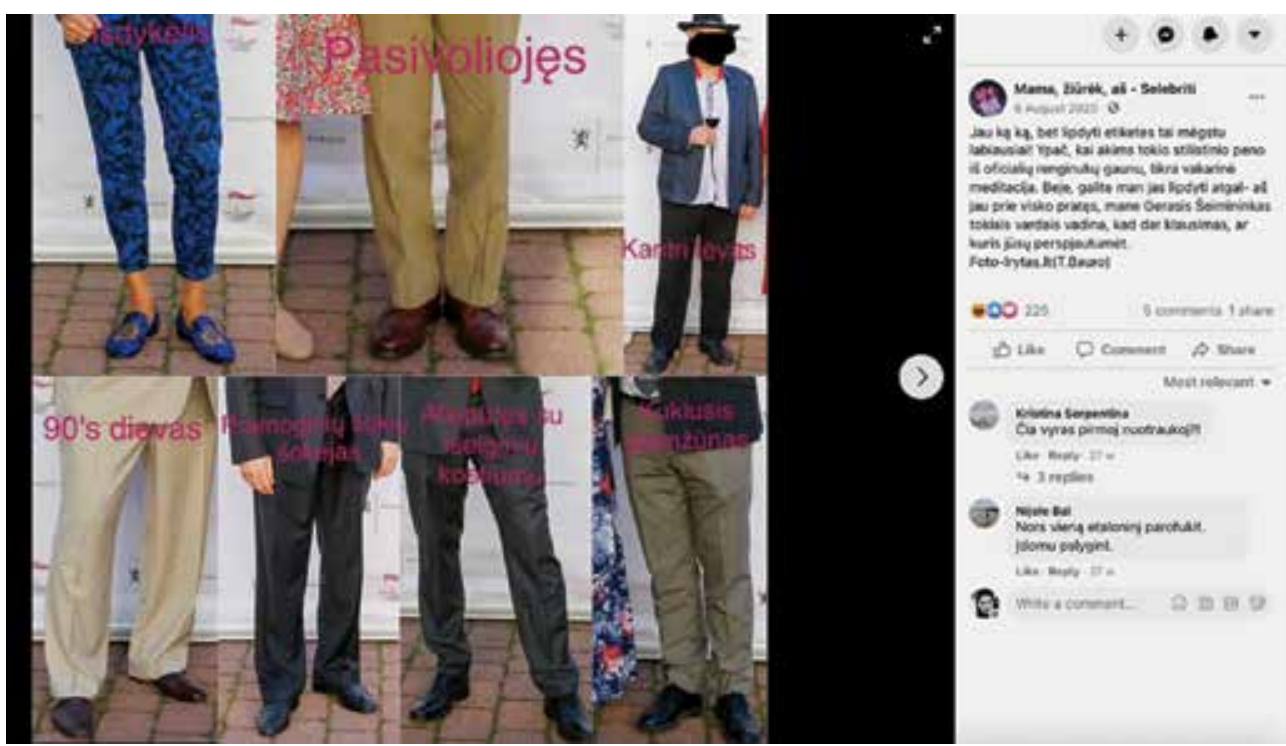

Fig. 5

'punctum' of the dress. In Fig. 1 it would be the image on the right, where skateblades are photoshopped onto the shoes of the wearer as well as the ice-arena background. In Fig. 3 it would be the largest image on the right, exhibiting Poodle's version of the dress, with the photoshopped Mercedes Benz logo visible instead of the original red strings. Parody as a genre is the one used most often by Poodle, it is at the core of the Pink Poodle fashion memes concept. Yet parody as a method for ironic representation is not the single technique used for Poodle's posts.

Finally, satire is defined by Kreuz and Roberts as the ridicule of a subject to point out its faults (Beckson \& Ganz in Kreuz \& Roberts 1993: 100). It differs from sarcasm in that it would address the society rather than an individual (ibid) which makes it a little less personal. In the case of Pink Poodle, the most explicitly satirical posts are related to mistakes in the protocol of dressing and - the most frequent cases - the inapropriateness of clothing worn in public because of its being wrinkled, crumpled or otherwise untidy.

For the expression of this type of satire, however, textual format is preferred over the visual. It means that the visual images do not represent a joke or an incongruity peculiar for a meme (or for visual irony). Poodle is serious about the importance of the subject, and the seriousness is emphasized by absence of 'memetic substance' in the visual part of posts. The exaggeration here is quantitative, achieved by cramming as many photographs as possible into one collage just to make it obvious that the volume of the problematic issue is large, it is a social trend. The satirical or ironic note comes through in the textual element of the post.

In Fig. 5, for example, as many as seven different types of wrinkled male trousers are collaged into a single image. Each of them is labelled, i.e., 'categorized' 
as a distinct type: "The Naughty One", "On a Rollercoaster", "Country Dad", "The 90's God", "Ballroom Dancer", "The Timid Crumpler", "The Relaxed in a Holiday Suit". The accompanying text claims: "Sticking labels is my most favourite occupation of all! Especially when my eyes get this kind of stylistic food from formal events, a real evening meditation. By the way, you may throw the labels back at me - I'm used to everything, the Good Master calls me by such names that raise doubts if any of you could surpass." Typologising untidiness is a satirical tool of social observation, while the irony of the remark about sticking labels being an evening meditation comes about when we realize that meditation is the opposite of public name-calling that the typology of wrinkled trousers really represents.

Presenting the generic differences of verbal irony, sarcasm, satire and parody, Kreuz and Roberts, like other authors before them, emphasize the role of the audience in the success of the ironic genres (Kreuz \& Roberts 1993: 100). They claim that verbal irony, sarcasm, satire and parody require an audience to maintain multiple representations of a text. In the case of verbal communication, the audience must perform the connection between the intention and the reality in an abstract way, 'in their mind's eye'. With memes - fashion and other - the audience is the witness of the irony being born right in front of their eyes, in its visual form, yet the necessity to maintain multiple representations remains - it is the multiple contexts that the audience has to juxtapose for themselves in order to perceive the irony of a meme. Poodle's memes do not explain what is funny in the image, they show it. Verbal text serves as a tool for commentary as well as contextualization.

The juxtaposition of a man in a blue suit and white shoes with an ice-skater in Fig. 1 would be meaningless if there was no explanation of the context - a party, with a hint of a fancy-dress party in this case. The comparison of similar outfits in Fig. 6 would have little sense if the audience was not informed that the female figure in a mask is a world-famous singer Billie Eilish and the outfit she was wearing for Billboard Music Awards was produced by Gucci. Juxtaposing it with typically Russian 'babushki' (grandmothers) dresses creates the intended contrast between a remote Russian village and a top-level world-famous event that requires appropriate clothing.

Parody requires the construction of multiple mental representations as well but, differently from satire, it relies on echoic mention (Kreuz \& Roberts 1993: 102). In order to be able to appreciate the parody, the audience must recognize it as one. A too big nose or too short legs will be merely funny (and may even seem offensive to some) if they do not know the original subject that is being parodied. If the audience does not recognize the personality of the woman in Fig. 3 as Kim Kardashian, the Poodle meme is a moderately successful parody of bad taste in underwear choices, so the mental representations required from the audience in this case is the celebrity image created by Kim Kardashian and the (in)appropriateness of underwear. Recognizing the personality of the 'protago- 

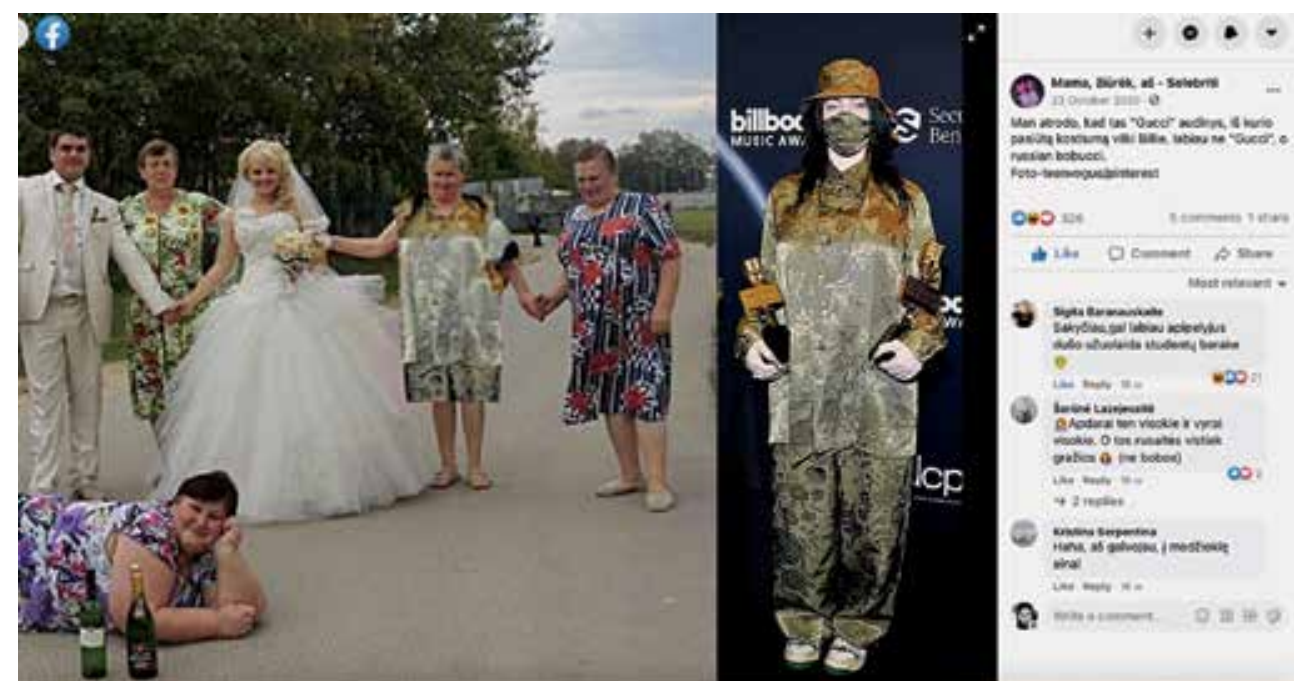

Fig. 6

nist' is equally essential for Fig. 6, but here at least three mental representations are necessary: the knowledge of the personality of the singer Billie Eilish, the concept of Gucci as an haute couture fashion brand, and the understanding about Russian village people and their probable aesthetic choices demonstrated in Poodle's image. Kreuz and Roberts claim that for an uninitiated reader a work of parody may mean nothing because "there is no "chorus" written into the parody to make this knowledge manifest. If the reader recognizes the resemblance between the parody and the original work, then the parody can succeed for that reader" (ibid, p. 103). For Pink Poodle memes, however, the risk of not being understood is too high to be taken - too complicated hints mean loss of the audience's interest. Therefore the recognition process is made easier by the texts that accompany the visual images of the posts. The textual part of the meme plays the role of 'chorus', ini- tiating the reader into the context of the meme. For example, in Fig. 2 the reader is told that the sheep-head hat is featured in Gucci collection; in Fig. 3 Kim Kardashian's red strings are related to the context of the year 2000, in Fig. 6 the reader is told the identity of the person wearing the Gucci suit (Billie Eilish) and the nationality of the old women in the other image (Russian "bobuchi"). The context frames the parody that is being created and transmits the message of ridicule successfully.

While in the case of verbal irony the audience must make the connection between the intention and the reality themselves by realising the mental representations in their mind's eye, with Poodle memes the audience is the witness of the visual irony being born in front of their eyes. Both the original subject and its parody or its satirical, sarcastic or ironic representations are conveniently organized together along with the 'chorus', or the context of the meme. 


\section{INSTEAD OF CONCLUSIONS}

The success of irony as a genre rests on the audience's ability to share the attitude of the ironist toward the incongruity between what is being said or shown and what is really meant by that verbal or visual expression. Pink Poodle memes represent a peculiar example of fashion memes because the ironic message is produced from the interaction between the visual incongruity and the textual elements of the meme.

The importance of visuality for the study of contemporary communication cannot be overestimated, and studies of

\section{Acknowledgements}

The author is sincerely grateful to Dr Pietari Kääpa for his valuable comments on this article.

\section{References}

Beckson K., Ganz A. 1989. Literary Terms: A Dictionary (3rd ed.). New York: Noonday.

Behler Ernst. 1993. German Romantic Literary Theory. Cambridge; New York: Cambridge University Press.

Colebrook Claire. 2004. Irony. London and New York: Routledge.

Denisova Anastasia. 2020. Internet Memes and Society: Social, Cultural, and Political Contexts. Routledge.

Dynel Marta. “I Has Seen Image Macros!” Advice Animal Memes as Visual-Verbal Jokes. International Journal of Communication 10(2016), Feature 660-688 1932-8036/2016FEA0002.

Hemplemann C., Samson A. 2008. Cartoons: Drawn jokes? V. Raskin (ed.). The Primer of Humor Research: 613-644. Berlin, Germany: Mouton de Gruyter.

Hutcheon Linda. 1994. Irony's Edge: The Theory and Politics of Irony. London: Routledge. irony are not an exception. The present article is a first attempt to analyze the mechanism of irony in fashion memes and does not exhaust the research potential that the field offers. Though the constantly developing memescape resists attempts of classification and categorization, researching generic distinctions of visual irony is a promising realm for further investigations.

Image credit: All images published with this text have been produced by Mama, žiūrèk, aš - Selebriti social media account and have been reprinted with their permission.

Kim Koh Woon. 2020. A case study on the contemporary fashion meme. The Research Journal of the Costume Culture 28 (3): 330-343.

Kreuz Roger J., Roberts Richard M. 1993. On Satire and Parody: The Importance of Being Ironic. Metaphor and Symbolic Activity, 8 (2): 97-109.

Magill Jay R., Jr. 2007. Chic Ironic Bitterness. The University of Michigan Press.

Marino Gabriele. 2015. Semiotics of Spreadability: A Systematic Approach to Internet Memes and Virality. Punctum, 1(1): 43-66.

Scott Biljana. 2004. Picturing Irony: The Subversive Power of Photography. Visual Communication. 3 (1): 31-59.

Skjulstad Synne. 2018. Vetements, Memes, and Connectivity: Fashion Media in the Era of Instagram. Fashion Theory, 24 (2): 181-209. 